\title{
The progressive fragmentation of the KIT/PDGFRA wild-type (WT) gastrointestinal stromal tumors (GIST)
}

\author{
Margherita Nannini ${ }^{*}$ (D), Milena Urbini ${ }^{2}$, Annalisa Astolfi ${ }^{2}$, Guido Biasco ${ }^{1,2}$ and Maria A. Pantaleo ${ }^{1,2}$
}

\begin{abstract}
Recent advances in molecular biology have revolutionized the concept of KIT/PDGFRA wild type (WT) gastrointestinal stromal tumors (GIST) than the past. Indeed, from being defined as GIST without KIT or PDGFRA mutations, we are now faced with the opposite scenario, where KIT/PDGFRA WT GIST are "positively" defined according to their specific molecular alterations. In particular, if until recently KIT/PDGFRA GIST without abnormalities of KIT, PDGFRA, SDH, and the RAS signaling pathway were referred as quadruple WT GIST, today also this small subset of GIST is emerging out as a group of heterogeneous distinct entities with multiple different molecular alterations. Therefore, given this still growing and rapidly evolving scenario, the progressive molecular fragmentation may inevitably lead over the time to the disappearance of KIT/PDGFRA WT GIST, destined to be singularly defined by their molecular fingerprint.
\end{abstract}

Keywords: GIST, SDH, Quadruple wild-type, ETV6-NTRK3, MEN1, MAX, FGFR1

Gastrointestinal stromal tumors (GIST) that lack KIT or platelet-derived growth factor receptor alpha (PDGFRA) mutations, that are around $10-15 \%$ of all cases, have always been classified as KIT/PDGFRA wild type GIST, short-named WT GIST [1]. Only recently, a more comprehensive molecular analysis have shown that KIT/ PDGFRA WT GIST are a rather heterogeneous group of different diseases than one single entity [2].

$20-40 \%$ of all KIT/PDGFRA WT GIST are succinate dehydrogenase complex (SDH)-deficient GIST, recognized by the loss of subunit B (SDHB) protein expression most often due to germ-line and/or somatic loss-of-function mutations in any of the four SDH subunits (A, B, C, or D). The SDH-deficient GIST share a pathognomonic profile characterized by young age, female gender predilection, gastric localization, mixed epithelioid and spindle cell morphology, diffuse KIT and ANO1 (DOG1) IHC positivity, frequent lymph node metastatic involvement, and an indolent behaviour even often metastatic up-front

\footnotetext{
*Correspondence: margherita.nannini@unibo.it

1 Department of Specialized, Experimental and Diagnostic Medicine, Sant'Orsola-Malpighi Hospital, University of Bologna, Via Massarenti 9, 40138 Bologna, Italy

Full list of author information is available at the end of the article
}

[3-9]. Moreover, SDH-deficient GIST are characterized by the over-expression of the insulin growth factor 1 receptor (IGF1R) [10, 11]. Finally, they also display a common epigenomic background, distinguished by a distinctive hypermethylation and miRNA profile [12-17]. In particular, SDH-deficient GIST present a marked hypermethylation profile, generally implicates the Krebs cycle as SDH-mutant paraganglioma and pheochromocytoma (Pgl/Pheo) [12]. Moreover, SDH-deficient GIST also show a distinctive miRNA expression profile characterized by miR-139-5p, 455-5p and let-7b signature, that may represent the epigenetic modulator of IGF1R expression and then a potential onco-miR mark of this subset of GIST [17].

The subgroup of the remaining KIT/PDGFRA WT GIST, but not SDH-deficient, have been further characterized: 4-13\% carry a BRAF V600E mutation, are localized more frequently in small intestine and seem to have a more favourable prognosis [18-21]. Within the not SDH-deficient, some GIST have a neurofibromatosis (NF) type 1 mutation and show a female prevalence, a frequent non-gastric site and multifocal localization often unveiling an unrecognized NF1 syndromic condition [22-26]. 
Half of the KIT or PDGFRA WT GIST have been identified to be either SDH-deficient or BRAF/RAS/NF1 mutated, but the other half has still remains orphan of a specific molecular event and thus has been named as quadruple WT-GIST [27]. However, the transcriptome profile of this small subgroup is so profoundly different from the other GIST, either KIT/PDGFRA WT or -mutated GIST, that quadruple WT GIST could represent another unique group within the family of GIST [28].

Nevertheless, recently it has been shown that quadruple WT GIST have a greater molecular heterogeneity, with many different and probably mutually exclusive mutational events (Fig. 1). The presence of an ETV6NTRK3 gene fusion has been firstly described in a case of rectal quadruple WT GIST [29]. The same translocation have been also reported in a colon primary quadruple WT GIST [30]. Moreover, two fusion genes involving FGFR1 were reported in three cases of quadruple WT GIST (FGFR1-HOOK3 and FGFR1-TACC1) [30]. Recently, other fusion events (KIT-PDGFRA, MARK2PPFIA1 and SPRED2-NELFCD) have also been detected [31, 32]. Finally, relevant somatic mutations, including TP53, MEN1, MAX, CHD4, FGFR1, CTDNN2, CBL, ARID1A, BCOR and APC were also identified [30-33]. Interestingly, MEN1 and MAX mutations, along with NF1 and SDH, further extend the list of genes detected in
KIT/PDGFRA WT GIST, genes which are characteristic for neuroendocrine tumors. Moreover, detection of high expression level of genes involved in the neural commitment process, such ASCL1 and EPHA4, further support the hypothesis of a neuroendocrine like signature for some quadruple WT GIST [32].

Given the recent findings, also quadruple WT GIST, the small subset of GIST that lack abnormalities of KIT, PDGFRA, SDH, and the RAS signalling pathway, can be considered as a group of heterogeneous single entities with different molecular alterations. Therefore, a different scenario than expected is emerging. Despite their unquestionable GIST morphology, given this marked molecular heterogeneity, quadruple WT GIST could be a different disease than GIST. Otherwise, trusting unquestionable GIST morphology, it could be argued that quadruple WT GIST may arise from a distinct population of pluripotent interstitial cells of Cajal (ICC) [34, 35], or that they may share a molecular driver at the epigenomic level, given their homogeneous gene expression profile.

If in the past KIT/PDGFRA WT GIST has been for long "negatively" defined by exclusion, we are now faced with the opposite scenario, where KIT/PDGFRA WT GIST are "positively" defined according to their specific molecular alterations. Over the time, this is inevitably leading to a progressive fragmentation of the KIT/PDGFRA WT GIST, until make them disappearing.

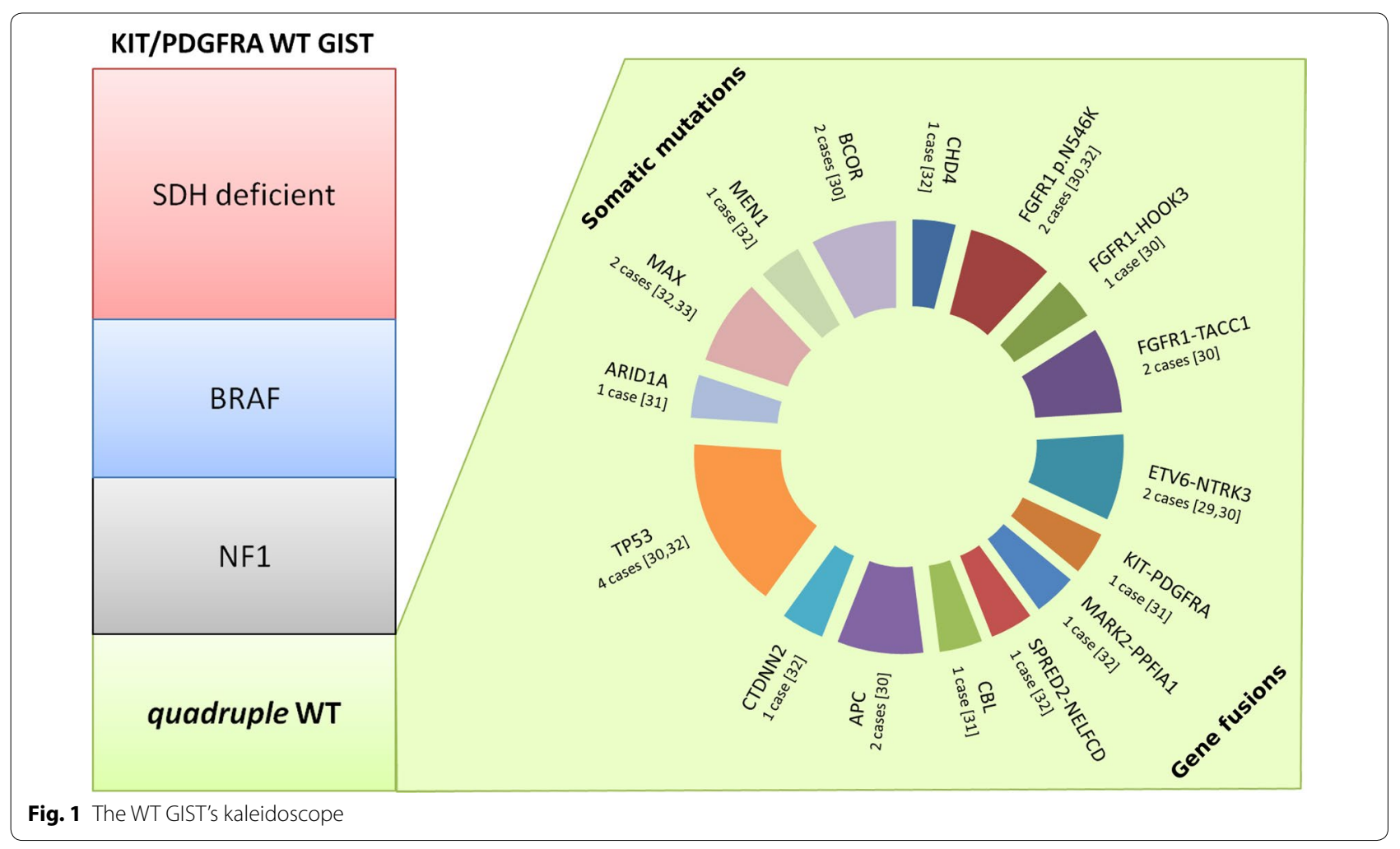




\section{Abbreviations}

GIST: gastrointestinal stromal tumors; PDGFRA: platelet-derived growth factor receptor alpha; WT: wild type; NF1: neurofibromatosis type 1; ICC: interstitial cells of Cajal; SDH: succinate dehydrogenase.

\section{Authors' contributions}

MN has made substantial contributions to conception of the manuscript and drafted the final manuscript. MU has carried out the figure. AA, GB, MAP have been involved in revising the manuscript critically for important intellectual content and have given final approval of the version to be published. All authors read and approved the final manuscript.

\section{Author details}

${ }^{1}$ Department of Specialized, Experimental and Diagnostic Medicine, Sant'Orsola-Malpighi Hospital, University of Bologna, Via Massarenti 9, 40138 Bologna, Italy. ${ }^{2}$ "Giorgio Prodi" Cancer Research Center, University of Bologna, Bologna, Italy.

\section{Acknowledgements}

Not applicable.

\section{Competing interests}

The authors declare that they have no competing interests.

\section{Publisher's Note}

Springer Nature remains neutral with regard to jurisdictional claims in published maps and institutional affiliations.

Received: 20 February 2017 Accepted: 16 May 2017

Published online: 23 May 2017

\section{References}

1. Corless CL, Fletcher JA, Heinrich MC. Biology of gastrointestinal stromal tumors. J Clin Oncol. 2004;22:3813-25.

2. Nannini M, Biasco G, Astolfi A, Pantaleo MA. An overview on molecular biology of KIT/PDGFRA wild type (WT) gastrointestinal stromal tumours (GIST). J Med Genet. 2013;50:653-61.

3. Gill AJ, Chou A, Vilain R, Clarkson A, Lui M, Jin R, Tobias V, Samra J, Goldstein D, Smith C, Sioson L, Parker N, Smith RC, Sywak M, Sidhu SB, Wyatt JM, Robinson BG, Eckstein RP, Benn DE, Clifton-Bligh RJ. Immunohistochemistry for SDHB divides gastrointestinal stromal tumors (GISTs) into 2 distinct types. Am J Surg Pathol. 2010;34:636-44.

4. Janeway KA, Kim SY, Lodish M, Nosé V, Rustin P, Gaal J, Dahia PL, Liegl B, Ball ER, Raygada M, Lai AH, Kelly L, Hornick JL, NIH Pediatric and WildType GIST Clinic, O'Sullivan M, de Krijger RR, Dinjens WN, Demetri GD, Antonescu CR, Fletcher JA, Helman L, Stratakis CA. Defects in succinate dehydrogenase in gastrointestinal stromal tumors lacking KIT and PDGFRA mutations. Proc Natl Acad Sci USA. 2011;108:314-8.

5. Miettinen M, Wang ZF, Sarlomo-Rikala M, Osuch C, Rutkowski P, Lasota J. Succinate dehydrogenase-deficient GISTs: a clinicopathologic, immunohistochemical, and molecular genetic study of 66 gastric GISTs with predilection to young age. Am J Surg Pathol. 2011;35:1712-21.

6. Pantaleo MA, Astolfi A, Urbini M, Nannini M, Paterini P, Indio V, Saponara M, Formica S, Ceccarelli C, Casadio R, Rossi G, Bertolini F, Santini D, Pirini MG, Fiorentino M, Basso U, Biasco G, GIST Study Group. Analysis of all subunits, SDHA, SDHB, SDHC, SDHD, of the succinate dehydrogenase complex in KIT/PDGFRA wild-type GIST. Eur J Hum Genet. 2014:22:32-9.

7. Pantaleo MA, Astolfi A, Indio V, Moore R, Thiessen N, Heinrich MC, Gnocchi C, Santini D, Catena F, Formica S, Martelli PL, Casadio R, Pession A, Biasco G. SDHA loss-of-function mutations in KIT-PDGFRA wild-type gastrointestinal stromal tumors identified by massively parallel sequencing. J Natl Cancer Inst. 2011;103:983-7.

8. Miettinen M, Killian JK, Wang ZF, Lasota J, Lau C, Jones L, Walker R, Pineda M, Zhu YJ, Kim SY, Helman L, Meltzer P. Immunohistochemical loss of succinate dehydrogenase subunit $\mathrm{A}(\mathrm{SDHA})$ in gastrointestinal stromal tumors (GISTs) signals SDHA germline mutation. Am J Surg Pathol. 2013;37:234-40
9. Pantaleo MA, Lolli C, Nannini M, Astolfi A, Indio V, Saponara M, Urbini M, La Rovere S, Gill A, Goldstein D, Ceccarelli C, Santini D, Rossi G, Fiorentino M, Di Scioscio V, Fusaroli P, Mandrioli A, Gatto L, Catena F, Basso U, Ercolani G, Pinna AD, Biasco G. Good survival outcome of metastatic SDH-deficient gastrointestinal stromal tumors harboring SDHA mutations. Genet Med. 2015;17:391-5.

10. Nannini M, Astolfi A, Paterini P, Urbini M, Santini D, Catena F, Indio V, Casadio R, Pinna AD, Biasco G, Pantaleo MA. Expression of IGF-1 receptor in KIT/PDGF receptor-a wild-type gastrointestinal stromal tumors with succinate dehydrogenase complex dysfunction. Future Oncol. 2013;9:121-6.

11. Belinsky MG, Rink L, Flieder DB, Jahromi MS, Schiffman JD, Godwin AK, Mehren Mv. Overexpression of insulin-like growth factor 1 receptor and frequent mutational inactivation of SDHA in wild-type SDHBnegative gastrointestinal stromal tumors. Genes Chromosom Cancer. 2013;52:214-24.

12. Killian JK, Kim SY, Miettinen M, Smith C, Merino M, Tsokos M, Quezado M, Smith WI Jr, Jahromi MS, Xekouki P, Szarek E, Walker RL, Lasota J, Raffeld M, Klotzle B, Wang Z, Jones L, Zhu Y, Wang Y, Waterfall JJ, O'Sullivan MJ, Bibikova M, Pacak K, Stratakis C, Janeway KA, Schiffman JD, Fan JB, Helman L, Meltzer PS. Succinate dehydrogenase mutation underlies global epigenomic divergence in gastrointestinal stromal tumor. Cancer Discov. 2013;6:648-57.

13. Mason EF, Hornick JL. Succinate dehydrogenase deficiency is associated with decreased 5-hydroxymethylcytosine production in gastrointestinal stromal tumors: implications for mechanisms of tumorigenesis. Mod Pathol. 2013;26:1492-7.

14. Killian JK, Miettinen M, Walker RL, Wang Y, Zhu YJ, Waterfall JJ, Noyes N, Retnakumar P, Yang Z, Smith WI Jr, Killian MS, Lau CC, Pineda M, Walling J, Stevenson H, Smith C, Wang Z, Lasota J, Kim SY, Boikos SA, Helman L, Meltzer PS. Recurrent epimutation of SDHC in gastrointestinal stromal tumors. Sci Transl Med. 2014:6:268.

15. Urbini M, Astolfi A, Indio V, Heinrich MC, Corless CL, Nannini M, Ravegnini G, Biasco G, Pantaleo MA. SDHC methylation in gastrointestinal stromal tumors (GIST): a case report. BMC Med Genet. 2015;16:87.

16. Kelly L, Bryan K, Kim SY, Janeway KA, Killian JK, Schildhaus HU, Miettinen M, Helman L, Meltzer PS, van de Rijn M, Debiec-Rychter M, O'Sullivan M, $\mathrm{NIH}$ Pediatric and Wild-Type GIST Clinic. Post-transcriptional dysregulation by miRNAs is implicated in the pathogenesis of gastrointestinal stromal tumor [GIST]. PLOS ONE. 2013;8:e64102.

17. Pantaleo MA, Ravegnini G, Astolfi A, Simeon V, Nannini M, Saponara M, Urbini M, Gatto L, Indio V, Sammarini G, Santini D, Ferracin M, Negrini M, Hrelia P, Biasco G, Angelini S. Integrating miRNA and gene expression profiling analysis revealed regulatory networks in gastrointestinal stromal tumors. Epigenomics. 2016:8:1347-66.

18. Agaimy A, Terracciano LM, Dirnhofer S, Tornillo L, Foerster A, Hartmann A, Bihl MP. V600E BRAF mutations are alternative early molecular events in a subset of KIT/PDGFRA wild-type gastrointestinal stromal tumours. J Clin Pathol. 2009;62:613-6.

19. Daniels M, Lurkin I, Pauli R, Erbstösser E, Hildebrandt U, Hellwig K, Zschille U, Lüders P, Krüger G, Knolle J, Stengel B, Prall F, Hertel K, Lobeck H, Popp $B$, Theissig F, Wünsch P, Zwarthoff E, Agaimy A, Schneider-Stock R. Spectrum of KIT/PDGFRA/BRAF mutations and Phosphatidylinositol-3-Kinase pathway gene alterations in gastrointestinal stromal tumors (GIST). Cancer Lett. 2011;312:43-54.

20. Rossi S, Gasparotto D, Miceli R, Toffolatti L, Gallina G, Scaramel E, Marzotto A, Boscato E, Messerini L, Bearzi I, Mazzoleni G, Capella C, Arrigoni G, Sonzogni A, Sidoni A, Mariani L, Amore P, Gronchi A, Casali PG, Maestro R, Dei Tos AP. KIT, PDGFRA, and BRAF mutational spectrum impacts on the natural history of imatinib-naive localized GIST: a population-based study. Am J Surg Pathol. 2015;39:922-30.

21. Jasek K, Buzalkova V, Minarik G, Stanclova A, Szepe P, Plank L, Lasabova Z. Detection of mutations in the BRAF gene in patients with KIT and PDGFRA wild-type gastrointestinal stromal tumors. Virchows Arch. 2017:470:29-36.

22. Andersson J, Sihto H, Meis-Kindblom JM, Joensuu H, Nupponen N, Kindblom LG. NF1-associated gastrointestinal stromal tumors have unique clinical, phenotypic, and genotypic characteristics. Am J Surg Pathol. 2005;29:1170-6.

23. Miettinen M, Fetsch JF, Sobin LH, Lasota J. Gastrointestinal stromal tumors in patients with neurofibromatosis 1: a clinicopathologic and molecular genetic study of 45 cases. Am J Surg Pathol. 2006;30:90-6. 
24. Bajor J. Gastrointestinal stromal tumors in patients with type 1 neurofibromatois. Clin Exp Med J. 2009;3:247-54.

25. Salvi PF, Lorenzon L, Caterino S, Antolino L, Antonelli MS, Balducci G. Gastrointestinal stromal tumors associated with neurofibromatosis 1: a single centre experience and systematic review of the literature including 252 cases. Int J Surg Oncol. 2013;2013:398570.

26. Gasparotto D, Rossi S, Polano M, Tamborini E, Lorenzetto E, Sbaraglia M, Mondello A, Massani M, Lamon S, Bracci R, Mandolesi A, Frate E, Stanzial F, Agaj J, Mazzoleni G, Pilotti S, Gronchi A, Dei Tos AP, Maestro R. Quadruplenegative GIST is a sentinel for unrecognized neurofibromatosis type 1 syndrome. Clin Cancer Res. 2017;23:273-82.

27. Pantaleo MA, Nannini M, Corless CL, Heinrich MC. Quadruple wildtype (WT) GIST: defining the subset of GISTs that lack abnormalities of KIT, PDGFRA, SDH, and the RAS signalling pathway. Cancer Med. 2015:4:101-3.

28. Nannini M, Astolfi A, Urbini M, Indio V, Santini D, Heinrich MC, Corless CL, Ceccarelli C, Saponara M, Mandrioli A, Lolli C, Ercolani G, Brandi G, Biasco G, Pantaleo MA. Integrated genomic study of quadruple-WT GIST (KIT/ PDGFRA/SDH/RAS pathway wild-type GIST). BMC Cancer. 2014;14:685.

29. Brenca M, Rossi S, Polano M, Gasparotto D, Zanatta L, Racanelli D, Valori L, Lamon S, Dei Tos AP, Maestro R. Transcriptome sequencing identifies ETV6-NTRK3 as a gene fusion involved in GIST. J Pathol. 2016:238:543-9.

30. Shi E, Chmielecki J, Tang CM, Wang K, Heinrich MC, Kang G, Corless CL, Hong D, Fero KE, Murphy JD, Fanta PT, Ali SM, De Siena M, Burgoyne AM, Movva S, Madlensky Heestand GM, Trent JC, Kurzrock R, Morosini D, Ross JS, Harismendy O, Sicklick JK. FGFR1 and NTRK3 actionable alterations in "Wild-Type" gastrointestinal stromal tumors. J Transl Med. 2016;14:339.
31. Boikos SA, Pappo AS, Killian JK, LaQuaglia MP, Weldon CB, George S, Trent JC, von Mehren M, Wright JA, Schiffman JD, Raygada M, Pacak K, Meltzer PS, Miettinen MM, Stratakis C, Janeway KA, Helman LJ. Molecular subtypes of KIT/PDGFRA wild-type gastrointestinal stromal tumors: a report from the national institutes of health gastrointestinal stromal tumor clinic. JAMA Oncol. 2016;2:922-8.

32. Pantaleo MA, Urbini M, Indio V, Ravegnini G, Nannini M, De Luca M, Tarantino G, Angelini S, Gronchi A, Vincenzi B, Grignani G, Colombo C, Fumagalli E, Gatto L, Saponara M, lanni M, Paterini P, Santini D, Pirini MG, Ceccarelli C, Altimari A, Gruppioni E, Renne SL, Collini P, Stacchiotti S, Brandi G, Casali PG, Pinna AD, Astolfi A, Biasco G. Genome-wide analyses identifies MEN1 and MAX mutations and a neuroendocrine-like molecular heterogeneity in quadruple WT GIST. Mol Cancer Res. 2017;15:553-62.

33. Belinsky MG, Rink L, Cai KQ, Capuzzi SJ, Hoang Y, Chien J, Godwin AK, von Mehren M. Somatic loss of function mutations in neurofibromin 1 and MYC associated factor $X$ genes identified by exome-wide sequencing in a wild-type GIST case. BMC Cancer. 2015;15:887.

34. Pantaleo MA, Astolfi A, Nannini M, Ceccarelli C, Formica S, Santini D, Heinrich MC, Corless C, Dei Tos AP, Paterini P, Catena F, Maleddu A, Saponara M, Di Battista M, Biasco G. Differential expression of neural markers in KIT and PDGFRA wild-type gastrointestinal stromal tumours. Histopathology. 2011:59:1071-80.

35. Beadling C, Patterson J, Justusson E, Nelson D, Pantaleo MA, Hornick JL, Chacón M, Corless CL, Heinrich MC. Gene expression of the IGF pathway family distinguishes subsets of gastrointestinal stromal tumors wild type for KIT and PDGFRA. Cancer Med. 2013;2:21-31.

\section{Submit your next manuscript to BioMed Central and we will help you at every step:}

- We accept pre-submission inquiries

- Our selector tool helps you to find the most relevant journal

- We provide round the clock customer support

- Convenient online submission

- Thorough peer review

- Inclusion in PubMed and all major indexing services

- Maximum visibility for your research

Submit your manuscript at www.biomedcentral com/submit

() Biomed Central 